\title{
The whaleblimp herder
}

Transport issues.

\section{Chris Butler}

The dog crouched down while the whaleblimp floated over it with a few inches of clearance, then scampered after it giving playful chase. Jones smiled and swung his crook through the grass, sending dandelion heads tumbling in the breeze.

In the distance he could see something, a cloud of dust kicked up from the land. He frowned, crouched down and pressed his hand to the ground. Men on horseback coming, he decided.

The sun was high in the sky so he kept in the shade of one of the whaleblimps. Crickets chirruped all around, but their sound was lost in the clatter of hooves and the rattle of a cart as the horsemen arrived. One of the whaleblimps was spooked and drifted off.

"Patch," Jones called to the dog. "Quit playing and start working."

Jones blew into his shepherd pipes and Patch got the idea. The dog bounded away and barked at the wayward blimp, bringing it back into the herd.

"Hey kid," one of the men said, and climbed down. He was little more than a kid himself, Jones thought, but he had the swagger of someone who fancied himself the leader of his group. "Name's River. Where're you going with these?"

Jones shifted the backpack on his aching shoulders and flapped away a fly buzzing round his face. The herd had slowed to a halt. He squinted against the sun and tried to figure how much these men might know about whaleblimps.

"I'm taking food and supplies to the people at the Moor power plant," he said.

River eyed the panniers suspended beneath the blimps. He nodded to his men and they pulled on the rope to drag one down, then hauled back the tarpaulin to inspect the cargo.

"You're lucky to have the power plant," Jones said. "I hear they couldn't keep York going any more."

River nodded. "Yeah, I heard that too. But see, you shouldn't just be herding these things across my land without asking first. There are tolls to be paid."

"I'm doing this for you," Jones said. "Without power ..."

River spat into the dirt. "Yeah, well, we need power but we also need to eat."

To Jones, the three men did not look like they were starving. The horses looked scrawny, though.

"My men are going to unload one of those panniers."

Jones sighed and nodded. He was getting used to this kind of trouble. Times were hard wherever he went. Not for the first time he thought it was a good thing the whale bioforms were inedible. His trade would have ended long before now.

"And if you want to take these back across my land after you're done," River said, "you better be able to pay me then, too."

\section{"But ..."}

River struck Jones with the back of his gloved hand, knocking him down. Patch barked angrily and ran forward.

"Quiet down, Patch," Jones said. He could let one knockdown go for now. He'd had worse before and it was not enough to deter him from what he had to do.

“Times are tough, kid," River said. "I'll take a fifth of whatever they're paying you. And I'll know what they've paid you, so don't try lying about that."

Jones figured that was a bluff. He watched while the men transferred the contents of the pannier onto their cart.

"I'll find you on your way back out of town," River said. "You shouldn't be too hard to spot."

A herd of airborne blimps could be seen for miles, and they moved slow. The three men rode away, hollering to each other and to the sky.

When Jones reached the power plant he pulled the papers from his backpack and showed them at the gate. "I'll need a word with your security people," he said.

"Sure," the guard said, "I'll have someone come down to talk to you. Meanwhile, if you'd like to take your herd through the gate, I'll call someone to hook up the blimps for you."

"Thanks."

Jones and Patch drove the herd inside. The supplies were unloaded and carried away. Then came the real purpose of the delivery. Jones watched as a team of men drained off the helium transported in the blimps. The gas had been taken out of the system at York. It would keep this plant's cooling system going for a while longer. York's loss was their gain.
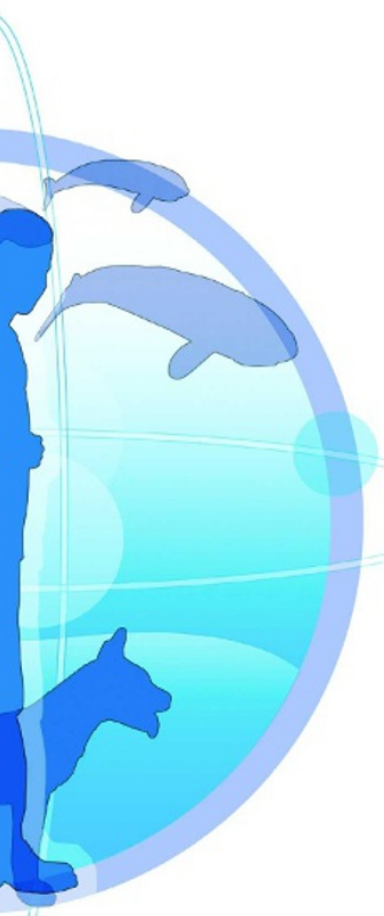

There was still a 岂 National Grid of sorts, and if they made sure they recycled whatever they could from the stations they closed, they could keep others going for a while yet.

Jones was loading his payment into his backpack when the head of security arrived to talk to him; the traded medical supplies were needed desperately back home at Harrogate.

"I had a guy named River making life difficult for me on the way over here," Jones said. "I'm not doing business with you again unless you keep control of the locals."

"People are getting desperate," he said, but he apologized. "We wouldn't want to lose a good courier like you."

Jones didn't know where his next helium cargo would take him. Maybe here. Maybe someplace else. "I don't want to see him again," he said.

A man came in with the blimps, vacuum sealed for the journey home. Jones put them in his backpack too. It was the easiest and safest way to transport them.

At the exit gate the guard said: "Hardly any Moon tonight."

Jones already knew the phase of the Moon, and left nothing to chance.

He pulled on his night vision goggles, whistled to Patch and set off on the long walk back.

Chris Butler's stories have appeared in Asimov's Science Fiction magazine and Interzone. His novel, Any Time Now, was published by Wildside Press. Latest news can be found at www.chris-butler.co.uk. 